\title{
DEVELOPMENT OF INNOVATION ACTIVITY AND DIVERSIFICATION OF THE MAIN DIRECTIONS OF THE STATE REGULATION IN AIC
}

\section{Natalia Shportyuk ${ }^{1}$}

DOI: https://doi.org/10.30525/978-9934-588-15-0-94

Abstract. In the current context, changes are in process the Ukrainian economy and they aimed at increasing the level of technological re-equipment, within which the agro-industrial complex needs a shift to an innovative development path. The article defines the concept of regional scientific and innovative potential, analyzes possible causes that hamper the development of innovative activity in agriculture, including the problems of the development of science. The article submits the priority directions for the development and improvement of mechanisms of state regulation of innovative processes in the AIC of Ukraine based on the analysis. Because of the strengthening of competitive principles in the country's agriculture, the stability of the position of the enterprise in the agricultural market, competitiveness and economic efficiency come to the fore. Continuous state of exploration for a rational model for the survival and further development of an agricultural enterprise in the context of changing market conditions in terms of consumer demand and the development of profitable product niches in the agricultural market leads to an increased role of production diversification as a factor working against market failures and consumer fluctuating demand. The right development of the strategy and tactics of an agricultural enterprise determines the type of diversification, specialization, concentration and production intensification. At the same time, in the native theory of management and economics, the problems of diversification are still insufficiently studied, which does not allow to maximize the reserves of its effectiveness in agricultural production. The article presents the importance of the innovative development of the Ukrainian AIC as a precondition for competitiveness in the agricultural market. It reveals the theoretical foundations of the industry innovation system of the AIC,

${ }^{1} \mathrm{PhD}$ in Public Administration, Associate Professor, Dnipro State Agrarian and Economic University, Ukraine 
the present state of the innovative development of the agricultural sector, including state regulation and informative and consulting support. The article provides a detailed analysis of the main directions of development of innovative processes in the field of AIC and land matters; it gives practical recommendations to improve the efficiency of innovative activities in agricultural production. The article analyzes the advantages of diversification strategies to reduce risks, in particular, agricultural enterprises under the conditions of the rules and the generally high instability of the current economic situation in Ukraine. There are measures that proposed to enhance the effects of diversification.

\section{Introduction}

Agriculture is one of the basic industry of the Ukrainian economy. In the current context, increasing the efficiency of agricultural production is assumed on the basis of industrial and innovative development, modernization and technical and technological re-equipment of agricultural production.

The economic mechanism for managing innovation is in a formative stage in Ukraine. New market conditions and the growth of scientific and technological progress are constantly making allowances to the technical and technological development of the country's agro-industrial complex, as a result of which the economic mechanism for implementing innovation policy should be constantly improved. The implementation of a new mechanism for managing scientific and technological development is possible only under the condition of constant state regulation of industrial and innovative development at all levels of the economy.

Analysis and evaluation of innovative activity in the state agriculture indicates that this process is characterized by a low level of innovative activity of business entities with significant scientific potential.

Scientific and innovative potential, indisputably, is the main driving force of scientific and technological progress in any branch of the national economy, and inter alia in the AIC.

The feature of the modern period of development of all sectors and areas of agricultural production is the need to accelerate scientific and technological progress on the ground of innovative processes, which allows for continuous updating of production based on the development of science, 
technology and best practices. International practices show that innovation processes, as a rule, are not only encouraged, but also regulated by the state through the policy formation and the systematic organization of innovative activities.

One of the priority areas of economic research is to understand the relationship between competitiveness, innovative diversification strategies, and institutional regulation in connection with the need to adapt the agro-industrial complex in the world economy. Methods of strengthening competitive advantages and institutional support should be adapted to the conditions of Ukraine's functioning in the WTO with the use of traditional and new methodological approaches: analysis, synthesis, modeling, informational support, expert judgment, etc.

The diversification strategy is the most effective for the development of innovative business models within the agro-industrial complex. In the context of economic modernization of the economy, whereas it is necessary to transfer it to an innovative development path, it is most advisable to use a diversification strategy in order to ensure immunity to upgrade modern agro-industrial complexes. Diversified areas of innovation activity provide competitive advantages in world markets: reduction of innovation risks, economic growth, cutback of spending while diversifying the industry. The experience of strategic management of diversified structures in other countries has shown that it may well be applicable in the conditions of modernization of Ukrainian agriculture through the innovative way of development [6, p. 64].

\section{Analysis of recent research and articles}

A comprehensive study of innovative development in the agricultural sector of the state economy is the subject of numerous articles. Among them are the works of O. Borodina, P. Gaidutsky, A. Erankin, T. Zinchuk, I. Kirilenko, M. Kropivka, Yu. Lopatinsky, Yu. Lupenko, V. Mesel-Veselyak, P. Sabluka, M. Fedorov and other.

The necessity and prospects of introducing diversification as an alternative strategic orientation of enterprises was substantiated by such foreign scientists as M. Porter, P. Kotler, G. Amstrong, A. Kukartseva.

The potential economic growth of the agrarian sector due to diversified production is the object of research by I. Grishov, V. Tkachuk, A. Tomilin, N. Stepanenko. 
Advantages and possible threats to diversification of enterprises, in particular agricultural ones, described in the works of D. Day, N. Maslak, A. Lemishko, A. Semenov, I. Ishenko, F. Vazhinsky, M. Korinko, L. Lozovsky, V. Lebedeva, T Panyuk.

However, these issues cannot be considered settled and sufficiently covered, therefore, the search for effective mechanisms and methods for solving them will continue to be of great interest to agricultural science and economic practice.

\section{Objective setting of the article}

The purpose is to analyze the main problems of the transition of the agricultural economy to the path of innovative development, highlighting the constraining factors of the innovative development of the AIC and determine the main directions of implementation of the state innovation policy, as well as to study the essence of the category "diversification of the main directions of state regulation in the AIC" and determine its place in ensuring competitive agricultural development and justification for the directions of diversification processes by agricultural enterprises under the current economic conditions.

\section{Summarizing of the key results and their validation. Factors in the creation and development of innovative processes in agriculture}

The innovation process is the process of converting scientific knowledge into innovation. The innovation process includes the following stages: "science - procedure (technology) - production - consuming." In the AIC, the innovation process is a constant stream of transformation of research and development into new or improved products, materials, new technologies, new forms of organization and management and bringing them to use in production process with a view to producing some outcome.

Any innovative activity starts from the moment of making an innovative decision. The grounds for adoption this decision remain the prerogative of the people who take it. The theory of innovations cannot give an unambiguous answer to the question: «which innovations will be more widespread and which directions of innovation development should be preferred?». World science has not yet developed a theory that would sufficiently describe the reasons for the implementation, the dynamics of the scale of innovation, the possible directions of its development. 
The results of the analysis of the economic and social development of the agro-industrial complex of recent years show that in Ukraine it is still applied so far eairlier and often inefficient agricultural technologies and unprofitable and labor intensive organizational and managerial methods and forms. There is no established interaction between enterprises in the real sector of the AIC and innovators due to the lack of proven mechanisms of activity, a system of scientific and technical information and reporting. There is no proven effective scheme for the interaction of scientific institutions with innovative structures. Extremely low innovation activity in the AIC is also associated with an ineffective organizational and economic mechanism for the development of innovations. This entails stagnation in the development of branches of the complex, leads to an increase in labor intensity, cost value and low quantitative and qualitative indicators of production, which contradicts the effective economic and social development of the countryside, and reduces the quality of life not only in rural areas, but also on a national scale [1, p. 57].

The detterents of the innovative development of the AIC are numerous. These include:

- poor management of STP, lack of close interaction between the government and private business;

- a sharp decrease in spending on agricultural science;

- incompetence of staff and its shortage;

- lack or insufficiency of marketing activities of enterprises;

- low level of effective demand for innovative products;

- reduced funding for the development of scientific and technological achievements in production and related innovative programs;

- the lack of development of mechanisms that stimulate the development of the innovation process in the AIC, and other reasons.

At the same time, the resource-producing sectors of the AIC, in many cases, continue to produce obsolescent inputs for agriculture, which, in exhange, involve the use of simplified technologies both in agriculture itself and in the related sectors of processing, storage and sale of agricultural products. This leads to a significant decrease in labor productivity in comparison with the best world analogues.

The development of conceptual issues of state technological policy and modern machine systems is a strategic prerequisite for the innovative updating of the AIC. 
In the long term, it is necessary to forecast and scientifically substantiate an agricultural at contractionary policy of importing food and directing the release of financial resources for the modernization and updating of the native AIC, strengthening the production and social infrastructure of the Ukrainian village. Such a strategic maneuver, relying on our own resources, will allow our country to quickly get rid of longstanding food dependence, make full use of one of the most powerful land potential in the world for the effective development of its agricultural production [3].

The creation and implementation of innovations in the agricultural sector of the economy is associated with an increased degree of uncertainty in obtaining a positive result. The results of this activity can bring success, but can put them in a predicament if the actual results of using the innovation turn out to be significantly lower than the expected results.

The stepping up of innovation activity is the main condition in the system of factors ensuring the development and increase of the efficiency of agricultural production in a market economy. Its fundamental element is innovation, which is the process of creating, developing, testing, evaluating, implementing and diffusion of product innovation. The innovation strategy is aimed at outperforming competitors, creating an innovation that will be recognized as unique. Therefore, the innovative strategy of agricultural enterprises is associated with the development of innovations that allow us to move to a new organizational and technological structure of production and ensure the competitiveness of products on the distribution markets. It should be noted that innovation activity is not limited only to activities for the development of innovations, but also provides assistance in the implementation of the innovation process, namely, management, investment and information activities [2, p. 88].

In the innovation activity of agriculture, new technology lie at the centre, which combines new knowledge, means of labor and objects of labor, work force, and it is intertwisted with socio-organizational changes and the qualification of labor as the most valuable and irreplaceable element of productive forces. Due to the lack of modern technologies, systems of machines for plant prodution, livestock breeding, etc., the agricultural sector is experiencing a period of technological backwardness. Currently, there are only a few fragments of technologies and types of technology that are significantly inferior to foreign analogues in their technical and economic parameters (reliability, performance). 
The specifics of the industry itself determines the features of the formation and development of innovative processes in agriculture. Agriculture as a branch of the economy is a complex system consisting of a number of subsystems, including: social, economic, technological, organizational, managerial and ecological. In connection with this agricultural structure, groups of factors are formed according to the degree of influence on production itself (branch, whole or an individual enterprise):

1. Technological group of factors.

2. Economic group of factors.

3. The social group of factors.

4. Institutional and management group of factors.

5. Ecological group of factors.

Each of the groups includes both external and internal factors. Among external factors, the factors of state regulation and market influence should be recognized as the main ones.

The factors of state regulation should include the system of administrative, legal and economic measures of influence on business entity (pricing system, tax, credit and financial insurance, budget support, labor stimulation, etc.).

Market factors of influence include the evolving level of prices for goods and services, labor remuneration, consumer demand, the supply and demand of competitors, the market for credit and insurance services, etc. [3, p. 167].

According to the subject and area of application of the agricultural sector, it is advisable to distinguish the following types of innovation: genetic selection; technical, technological and industrial innovation; organizational and managerial, economic innovation; socio-environmental innovation

The first type of innovation is inherent only in agriculture.

Technological factors of production are classified according to the subsectors of agriculture (arable farming, crop production, livestock breeding) and their service sectors (mechanization, energy supply and automation of the industry, processing and storage of agricultural products, transport services, etc.).

The primary factors in this group are: climatic conditions, soil fertility, varieties of agricultural plants, animal breeds, farming systems, crop production and livestock production technologies, including soil cultivation systems, fertilizers, plant protection products, time frame of agricultural activities in a specific zone, subzones and other numerous factors. 
Table 1

Classification of types of innovation in agriculture

\begin{tabular}{|c|c|c|c|}
\hline $\begin{array}{l}\text { Genetic selection } \\
\text { innovation }\end{array}$ & $\begin{array}{l}\text { Technical, } \\
\text { technological } \\
\text { and industrial } \\
\text { innovation }\end{array}$ & $\begin{array}{l}\text { Organizational } \\
\text { and managerial, } \\
\text { economic } \\
\text { innovation }\end{array}$ & $\begin{array}{c}\text { Socio- } \\
\text { environmental } \\
\text { innovation }\end{array}$ \\
\hline $\begin{array}{l}\text { New varieties } \\
\text { and hybrids of } \\
\text { agricultural plants } \\
\text { New breeds, types } \\
\text { of animals and } \\
\text { birds } \\
\text { Creation of plants } \\
\text { and animals } \\
\text { resistant to diseases } \\
\text { and pests, adverse } \\
\text { environmental } \\
\text { factors }\end{array}$ & $\begin{array}{l}\text { Usage of new } \\
\text { machinery } \\
\text { New crop } \\
\text { cultivation } \\
\text { technologies } \\
\text { New industrial } \\
\text { technologies in } \\
\text { animal husbandry } \\
\text { Science-based } \\
\text { farming and } \\
\text { livestock systems } \\
\text { New fertilizers and } \\
\text { their systems } \\
\text { New plant } \\
\text { protection products } \\
\text { Arable farming } \\
\text { biologization and } \\
\text { ecologization } \\
\text { New resource- } \\
\text { saving technologies } \\
\text { for the production } \\
\text { and storage of food } \\
\text { products aimed } \\
\text { at increasing the } \\
\text { consumer value of } \\
\text { food products }\end{array}$ & $\begin{array}{l}\text { Development of } \\
\text { cooperation and } \\
\text { the formation of } \\
\text { integrated structures } \\
\text { in the AIC } \\
\text { New forms of } \\
\text { maintenance and } \\
\text { supply of resources } \\
\text { in AIC } \\
\text { New forms of labor } \\
\text { organization and } \\
\text { motivation } \\
\text { New forms of } \\
\text { organization and } \\
\text { management in the } \\
\text { AIC } \\
\text { innovation } \\
\text { marketing } \\
\text { Creation of } \\
\text { innovation and } \\
\text { consulting systems } \\
\text { in the field of } \\
\text { scientific, technical } \\
\text { and innovative } \\
\text { activity } \\
\text { Concepts, decision } \\
\text { making methods } \\
\text { Forms and } \\
\text { of innovative } \\
\text { development }\end{array}$ & $\begin{array}{l}\text { Creation of the } \\
\text { personnel system } \\
\text { of scientific and } \\
\text { technical support } \\
\text { for the AIC } \\
\text { Improving of } \\
\text { working conditions, } \\
\text { solving the } \\
\text { problems of health } \\
\text { care, education } \\
\text { and culture of rural } \\
\text { workers } \\
\text { Enhancement } \\
\text { and improving } \\
\text { the quality of the } \\
\text { environment } \\
\text { Ensuring favorable } \\
\text { environmental } \\
\text { conditions for life, } \\
\text { work and recreation }\end{array}$ \\
\hline
\end{tabular}


The economic group of factors also has a complex classification. The primary definitions of factors include prices for acquired working capital and fixed assets, prices for the sale of agricultural products through various channels, the system and level of taxes, and many others.

The social group of factors covers the labor protection system, the level of income by groups of workers, staffing; demographic situation.

The recovery of the agrarian economy from the crisis, the stable functioning of agriculture, as well as other areas of the AIC, ensuring the competitiveness of native food is inextricably linked with the activation of innovative processes [4, p. 168].

Analysis of the socio-economic situation in the agricultural sector of the last post-reform years shows that outdated technologies, plant varieties and livestock breeds, imperfect methods and forms of organizing production and management are used here. There are no well-established mechanisms for acceptable activities, a system of scientific and technical information corresponding to a market economy, and there is no proven effective scheme for the interaction of scientific institutions with innovative structures. Extremely low innovation activity is also associated with the imperfection of the organizational and economic mechanism for the development of innovations. This enhances the degradation of the industries of the complex, leads to an increase in cost and low competitiveness inhibits the socio-economic development of rural areas, dramatically reduces the quality of life in rural areas.

Innovative processes in the agricultural sector have their own specifics. They are distinguished by a variety of regional, industry, functional, technological and organizational features. An analysis of the conditions and factors affecting the innovative development of AIC allowed us to divide them into negative (constraining innovative development) and positive (contributing to the acceleration of innovative processes).

The conditions and factors contributing to the innovative development of the AIC are the transition to a market-based method of managing, the availability of natural resources, significant scientific and educational potential, a capacious domestic food market, and the ability to produce environmentally friendly, natural food products.

As negative conditions for factors, we should note departmental disunity and weakening of the scientific potential of agrarian science. Native 
agricultural science is characterized by: a high degree of complexity of the organizational structure and departmental disunity (the multiplicity of ministries and departments involved in solving agricultural problems); a variety of forms of scientific, technical and innovative activity; a significant proportion in scientific research of problems of a regional, sectoral and intersectoral nature; a long study of some problems associated with the reproductive process. This specificity creates certain difficulties in the management of agricultural research and agricultural science in general.

The decrease in appropriation to science over the years of reform has led to an outflow of young scientists.

One of the features of agriculture is that, living organisms - animals and plants - take an active part in the reproductive process along with industrial means of production. Their development is subject to the action of natural laws and depends on such natural factors as climate, weather, heat, moisture, light and food.

Enhanced reproduction in agriculture proceeds in the combination with economic and natural biological processes. Therefore, when managing innovations, it is necessary to take into account the requirements of not only economic laws, but also the laws of nature: the equivalence, irreplaceability and combination of life factors, the laws of minimum, optimum and maximum. The effect of the law of the indispensability of production factors is manifested in the fact that, for example, selection cannot be compensated for with fertilizer, defects of agricultural machinery cannot be compensated for cultivar, and feed cannot be compensated for breeding. According to the law of the minimum, production growth is constrained by the factor that is at the minimum. For example, the substance, the largest amount of which is in the feed ration, determines the level of livestock productivity; in accordance with the law of maximum, the excess of any one nutrient over the needs of the animal will not lead to an increase in its productivity.

The complex nature of innovations in the AIC imposes specific requirements on the innovative mechanism (the regulatory framework for innovative development, organization and management, innovative marketing, and the development of an innovative structure).

It should be noted that the complexity and features of agricultural production are characterized by a high level of risks of innovative processes in the agricultural sector. The risk of financing research and production results, 
the risk of a temporary gap between costs and results, and the uncertainty of demand for innovative products hinder private investors from investing in agricultural development.

The conditions and factors that impede the development of innovations in the agro-industrial complex also include the contraction of native food demand, the reduction of state support for the agricultural sector and state financing of scientific and technical programs, the underdeveloped lending system, high credit aid rates, the lack of innovative infrastructure and state innovation policy and strategy, insufficient level of training of personnel of the agro-industrial complex organizations in the field of innovation management [4, p. 170].

A number of factors brake the increase in innovation activity in agriculture:

1. Inconsistency of the existing scientific, technical and technological potential of agriculture with new economic and production requirements. The decline in agricultural production, the weak support from the state and the high cost of innovation do not allow to develop innovation.

2. The inequality of the exchange of agriculture with other sectors of the economy remains, leading to the degradation of its material and technical base. Rising energy prices significantly worsen the situation, which deprives native agricultural producers of their natural advantage.

3 . The main reason is the unfavorable investment situation for agriculture and the low profitability of most agricultural producers. Despite the fact that the investment process in agriculture has noticeably intensified in recent years, its share in the expenditure is very small. The economy of most agricultural producers is such that it does not allow them to carry out not only expanded, but also simple reproduction, and to use the economic incentives provided by the state. Resources for innovation are much less than what is needed for agricultural development. In addition, over the past five years, the share of own funds of agricultural organizations allocated for investment in fixed assets has significantly decreased, which is not only a limiting factor in the innovative development of agriculture, but also creates a threat of repayment of received credit aid.

Among the priorities for the modernization of agriculture, the following should be highlighted:

- increasing the investment attractiveness of the industry for private investors, including foreign ones; 
- increasing the growth rate of technical re-equipment of agricultural producers;

- the development of social infrastructure in rural areas contributes to the increase of qualified personnel;

- the development of new technological processes on an innovative basis [1].

Given the situation, we consider expedient developing innovative processes in the agriculture of Ukraine in the following main areas:

1) technical and technological re-equipment of enterprises;

2) organization of an effective mechanism for managing innovative activities in agricultural production at the regional level;

3 ) integration of small enterprises, large production units on the basis of co-operation, to take advantage of large enterprises;

4) activation of innovative activity of economic entities;

5) increasing in the effectiveness of scientific research.

The first focus area should provide, foremost, the technical re-equipment of enterprises, overcoming the industrial backwardness of agricultural production.

The second focus area consider the formation of a mechanism for managing innovation in agriculture at the regional level, which will ensure the creation of a system of information and infrastructural support for innovation processes.

The buildup of innovative infrastructure, in line, involves the creation of organizations to promote scientific and technical products on the innovation market; information and advisory support for innovation; examination of scientific and innovative programs, projects, proposals and applications; development of a research base; creation of structures for financing scientific, technical and innovative activities.

The third focus area in the development of innovation may be the integration of small agricultural and processing enterprises (including private farming enterprises) into large structures with great financial capacity.

The fourth focus area involves the mainstreaming of innovative activities of agricultural enterprises through the provision of tax benefits, improved financing, and the expansion of the provision of information services.

The fifth focus area involves increasing the responsibility of research and other enterprises for the results of innovation.

Only permanent scientific and technological progress can ensure the dynamic development of modern society. Its main conditions are contin- 
uous updating of technologies and widespread use of the latest scientific developments.

Today, the Ukrainian scientific community is unanimous in the opinion that the most reliable way to overcome the crisis from agriculture is to develop its innovative foundation. Increasing innovation activity will not only help to increase the technical and economic level of production, but also significantly improve the investment environment [6, p. 55].

Only through common effort of the state, science and agricultural enterprises can in the long term increase innovative activity in the country's agriculture. This will not only increase production efficiency, but also its competitiveness in the international food market [7, p. 12].

The innovative type of development of the agricultural economy is largely determined by the scientific and technical policy of the region, the formation of a regional innovation mechanism. Innovators have an important role in the implementation of the anti-crisis program, using innovations of the selection-genetic, technological, organizational-managerial and social type.

Among the priorities for the development of innovative processes in the regional AIC are:

- technological re-equipment of complex organizations;

- energy and resource saving technologies for the production, storage and processing of agricultural products;

- reproduction of soil fertility, prevention of all types of their degradation, development of adaptive technologies of agricultural ecosystems and cultivated lands;

- development of organic agricultural products. Ukraine has a unique opportunity to concentrate on its huge land resources and the production of ecologically safe products, to develop organic farming technologies;

- Creation of a modern system of information and infrastructural support for innovation in the AIC;

- development of state innovation policies and strategies at the state and regional level, aimed at the formation of progressive technological structures;

- the buildup of the organizational and economic mechanism for the functioning of the AIC on an innovative basis;

- strengthening of the role of state organizations in enhancing innovation;

- the development of regional and municipal innovative AIC development programs; 
- improving of the training system in the field of innovation, providing increased innovation activity of organizations and the commercialization of research results.

\section{Diversification of the main directions of state regulation in the AIC}

The restoration and further development of agriculture is associated with the solution of complex sectoral and intersectoral problems. In this regard, the importance of state targeted programs, the solution of important regional problems, the development of territorial-industrial complex is growing. The acceleration of their solution in modern conditions will largely depend on the activation of innovative processes in the industry. Innovative processes in agriculture should be constantly regulated by the state on the basis of an approved program, the implementation of which will contribute to the organizational, economic, technological and technical modernization of agricultural production, increase its efficiency, development and improvement of the social sphere in rural areas.

As for the various sectors and spheres of the national economy, the essence of innovation does not differ fundamentally, while the nature and direction of the innovation process in them can differ significantly. The innovation process in the AIC has its own specifics, due to the peculiarities of agricultural production, and, above all, its main component - agriculture. Innovation activity in the conditions of agricultural production is the process of creating, testing and further implementing of innovations in any element of the organizational system - an innovation in technology, equipment, elements of organization and management, which lead to progressive changes in the nature of life.

Such activity is not limited to the purely technical side, but represents the unity of technological, technical, organizational, managerial and social innovations.

Diversification as a form of economic relations of economic entities is a pattern of existence and innovative development of agro-industrial systems.

In exchange, diversification has its own laws of development:

- equalization of industry profitability;

- elimination of imbalances in agricultural reproduction;

- transformation and dynamic stability. 
The effect of diversification is expressed in the appearance of new types of products and services, changes in sectoral, intersectoral and regional proportions. Diversification can be carried out in order to obtain economies of scale and the expansion of activities.

In the AIC, diversification is carried out through the vertical integration of agricultural producers and industrial processing enterprises, organizations providing financial services - the production and investment area, understood as expanding the scope of activities. Horizontal, conglomerate diversification is common in agriculture. The main types of diversification strategy in AIC is diversification by product and by region [8, p. 106].

The necessity of modernizing the economy in the conditions of the agricultural crisis, functioning in the WTO requires strengthening the competitive position of the agricultural sector of Ukraine on the way of its innovative development. The low innovative susceptibility of the AIC, the loss of a significant part of the scientific and technical potential, the negative aspects of the state of the world economy require measures to improve governance in the agricultural sector, it needs a fundamentally new approach which reflects the influence of external and internal factors of innovative development, their interaction with state regulation.

An innovative diversification strategy is effective for large structures. The variety of types of this strategy allows each company to find a development model that suits it and contributes to the sustainability to updating. Diversified areas of innovation provide competitive advantage.

The innovative form of diversification is clusters consisting of competitive market participants within individual industries and local entities. However, the development of effective diversified clusters is possible only if there is an effective regional strategy, since their development in isolation from the region is not effective.

A cluster is a complex based on industry or territorial concentration and diversification of networks of manufacturers, suppliers and consumers connected by a single technological chain. The cluster also includes infrastructure organizations that provide service, logistics, and research services [5].

Management in innovative clusters ensures the efficiency of diversification of reproduction processes in agriculture, which means the creation of optimal reproductive proportions, and it directly depends on the efficiency of diversification of microeconomic systems. The synergistic effect 
of diversification is to obtain more net profit from a diversified system than the amount of net profit that is part of its economic systems, which operate independently. The components of the synergy effect are saving investment, saving costs, saving time of the reproduction process.

The specifics of the functioning of the agro-industrial complex is a low level of diversification processes, local content in manufacturing, and insufficient financial support for innovation. The combination of these factors and features determines the specifics of measures to strengthen the competitive position of the AIC at the macro-, meso- and micro-levels.

Among the actions that are important are: support for oligopoly markets, support for the export of native food, support for high-tech industries, improve the activities of territorial chambers of commerce for certification and standardization of agricultural products, stimulate the diversification of agricultural and food markets through the development of medium and small enterprises, market infrastructure - banking, insurance, advertising, transport, trade services, import-substituting products.

Supportive measures should be directed by institutional structures to create the necessary conditions for overcoming the innovation pause, developing of healthy competition, and reducing entrepreneurial risks. It is important to prohibit contracts for the sale and leasing of fixed assets and goods, if their conditions for limiting interfacing sales weaken competition. Particularly topical are measures to develop information-analytical and innovative infrastructures, creating conditions for the interaction of infrastructure and business production components. This requires the diversification of infrastructure support programs for entrepreneurship in the AIC [7, p. 14].

The exposure of modern trends of diversification, accompanied by a change in the structure of production organization, is facilitated by the method of establishing quantity-related dependence in related and unrelated sectors of agricultural production, which contains the calculation of an integrated index, the value of which indicates structural changes within the industry. The indicator helps to assess the nature of structural shifts between manufacturing, but related areas - crop and livestock, between core and non-core activities. Calculations of integral indicators confirm the existence of various levels of diversification, and the regions with a higher indicator have the advantages of further development. 
The combination of several types of activity in one economic system inevitably leads to institutional diversification - in the field of state support and the provision of financial services. Diversification is implemented by providing credit resources for various types of activities, using budget funds to finance government support measures for agricultural producers.

Diversification is needed in the assignment of state support and credit resources in the AIC for various types of activities, the use of budgetary funds to finance the aforementioned activities, in particular, on products purchased by agricultural producers on leasing terms.

State support should be aimed at deepening intrabranch specialization and related diversification, stimulating the development of small business forms in order to strengthen functional diversification [8, p. 106].

In modern conditions, diversification is narrowing because of concentration of credit resources issued to large agricultural enterprises in the form of LLCs $-73-85 \%$ of the overall volume of originated loan, concentration and specialization of credit services of banks are increasing. It is necessary to stimulate the diversification of banking services in order to expand the access of rural producers to credit and financial resources through the expansion of the banking network and credit cooperative society in rural areas.

The list of services to rural producers included in the system of state standards, the development of which is provided for in the Concept of Sustainable Development of Rural Territories for the period up to 2020, should provide for the bank services accomplishment on a stationary basis depending on the number of rural population in the regions. It can be provided through state order for a service among lending agency on a competitive basis. The strengthening the competitive position of the agro-industrial complex on the basis of clustering as an innovative option for diversification is associated with the situation in a particular market, the level of interconnection of external and internal factors and their impact on demand, the interaction of state regulation factors and institutional support [6, p. 56].

\section{Summary and directions for future research}

In this respect, it is extremely important to establish a hierarchical relationship between competitive positioning, institutional regulation, diversi- 
fication of activities, and the integration of innovative agro-industrial complex modernization programs.

Elements and structured relations of the mechanism for strengthening the competitive position of agricultural producers, regardless of the hierarchy of links in the global agricultural market, should be modified to implement the strategy of innovative diversification of activities through the formation of innovative clusters in order to modernize the economy along the innovative path of development.

\section{References:}

1. Antonyuk L.L. (2003). Innovatsiyi: Teoriya, mekhanizm rozrobky ta komertsializatsiyi: monohrafiya. Kyiv: Vyd-vo KNEU, 394 p.

2. Bilozor L.V. (2012). Metodolohichni pidkhody shchodo formuvannya innovatsiynoyi produktsiyi. Ekonomika APK, no. 9, pp. 88-93.

3. Honcharenko O.V. (2016). Instytucionalni aspekty realizaciyi innovacijnyx priorytetiv rozvytku agropromyslovogo vyrobnycztva. Efektyvne upravlinnia, Ekonomika. Upravlinnia. Innovatsii. Seriia: Ekonomichni nauky.

4. Hotra V.V. (2015). Investycijni peredumovy formuvannya innovacijnogo potencialu APK. Stalyj rozvytok ekonomiky, vol. 2, pp. 167-177.

5. Disposition of the Cabinet of Ministers the Concept of the State Target Program for the Sustainable Development of Rural Territories for the Period till 2020 № 121-p. (2003, February 03). Retrieved from: https://www.kmu.gov.ua/ua/ npas/243284424

6. Koreczkyj B. (2005). Diagnostyka typiv dyversyfikaciyi diyalnosti u sub'yektiv gospodaryuvannya. Zb. nauk. pracz kafedry ekon. analizu Ternopilskoyi akademiyi nar. gosp-va, no. 14, pp. 53-55.

7. Korinko M.D. (2009). Dyversyfikaciya yak strategiya rozvytku. Aktualni problemy ekonomiky, no. 5, pp. 12-17.

8. Lemishko O.O. (2001). Dyversyfikaciya - najvazhlyvishyj faktor pidpryyemnyczkoyi diyalnosti u silskogospodarskyx pidpryyemstvax Luganskoyi oblasti. Ekonomika APK, no. 4, pp. 106-110.

9. Stepanenko N.I. (2010). Mexanizm formuvannya strategiyi dyversyfikaciyi agroservisnyx pidpryyemstv. Vseukrayinskyj naukovo-vyrobnychyj zhurnal, no. $1(15)$, pp. $18-21$.

10. Tomilin O.O. (2012). Dyversyfikaciya agrarnyx pidpryyemstv yak diyeva strategichna oriyentaciya v agropromyslovij sferi. Zb. nauk. pr. VNAU. Seriya «Ekonomichni nauky», no. 3(69), pp. 205-211. 